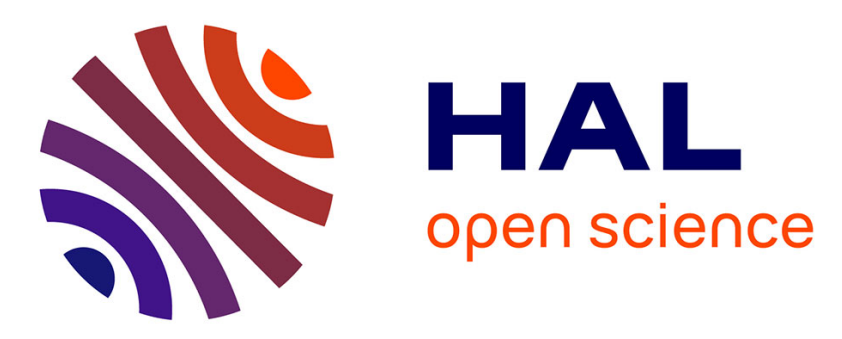

\title{
Analysis of the indoor propagation losses for the portable phone "Pointel"
}

Gheorghe Zaharia, Ghais El Zein, Jacques Citerne

\section{To cite this version:}

Gheorghe Zaharia, Ghais El Zein, Jacques Citerne. Analysis of the indoor propagation losses for the portable phone "Pointel". IEEE-APS International Symposium, Ann Arbor, Michigan, 1993, Jun 1993, Ann Arbor, United States. pp.1069-1072, 10.1109/APS.1993.385164 . hal-00875616

\section{HAL Id: hal-00875616 https://hal.science/hal-00875616}

Submitted on 31 Oct 2013

HAL is a multi-disciplinary open access archive for the deposit and dissemination of scientific research documents, whether they are published or not. The documents may come from teaching and research institutions in France or abroad, or from public or private research centers.
L'archive ouverte pluridisciplinaire HAL, est destinée au dépôt et à la diffusion de documents scientifiques de niveau recherche, publiés ou non, émanant des établissements d'enseignement et de recherche français ou étrangers, des laboratoires publics ou privés. 


\title{
ANALYSIS OF THE INDOOR PROPAGATION LOSSES FOR THE PORTABLE PHONE "POINTEL"
}

\author{
Gh. Zaharia*, G, El Zein and J. Citerne \\ Laboratoire Composants \& Systèmes pour Téléccommtanications \\ URA CNRS 834, INSA, 35043 Rennes Cédex, France
}

\section{A BSTRACT}

The results of power loss measurements for the portable phone "Pointel" opcrating in the $864 * 868 \mathrm{MHz}$ band are presented. These measurements were performed in the frequency domain using a network analyzer. Three indoor environments were considerad for propagation experiments. Three methods fot the power loss analysis are also described. From the obtained results, the radio coverage with both line-of-sight and obstruction of the direct path is derived.

\section{INTRODUCTION}

The measurements described in this paper were performed for the ponable phone "Pointel", developed by SAT T-Paris. This system operates in the 864 - 868 $\mathrm{MHz}$ frequency band and has 40 channels with $100 \mathrm{KHz}$ bandwidth. For such a system, the well known global analysis [1]. [2] is not sufficient. Indeed, the results given in this paper shows that the paraneters of the relationship between the power loss and the distance between antennas are frequency-dependent in the considered frequency band. For this reason, the analysis was also carried out for each channel of the system. The obtained results are used to estimate for each channel the radio coverage. The comparison with the radio coverage estimated with the global method shows the utility of the analysis for each chasnel.

\section{DESCRIPTION OF THE MEASUREMENTS}

The measurement system [3] is built up around a HP $8753 \mathrm{C}$ network analyzer which generates a swept frequency signal from $864 \mathrm{MHz}$ to $868 \mathrm{MHz}$ in 801 equally spaced steps and arialyses the received signal. The output of the network analyzer is connected to the transmitting (Tx) antenna through a $50 \mathrm{~m}$ coaxial cable with $8 \mathrm{~dB}$ attenuation. The calibration is performed at the output of this cable. The signal from the receiving $(\mathrm{Rx})$ antenna is returned through a 4.5 m coexial cable to the networt analyzer to determine the $S_{21}$ parameter. For cach location of the $\mathrm{Rx}$ antenna, the magnitude of $S_{21}$ was reconded.

Measurements were carried out in two different buildings: the principal building of INSA (The National Institut of Applied Sciences) and the railway station at Rennes. The environments considered in this paper consist of one contdor in the building of INSA and ane corridor in the first floor of the railway stztion. For the first environment, the line-of-sight (LOS) was assured for each location of the Rx antenna (INSA-LOS). At the railway station, in the first situation, a similar scenario was chosen (R.ST.-LOS). For the second situation, the LOS was obstructed (R.ST.-OLOS).

The Tx antenna was elevated at $2.25 \mathrm{~m}$. For each location of the $\mathrm{Rx}$ antenna, two values for its height were considered: $1.7 \mathrm{~m}$ and $1.2 \mathrm{~m}$. During the measurements, both antennas wert kept fixed. Conceming the time invariance of the channel, the measurements were petformed during the night, in order to avoid the effects of the presence of people. The surrounding environment was kept sationary by preventing movements during the data acquisition.

In order to reduce the measurement noise, for each position of the $\mathrm{Rx}$ antenna, four measurements were performed (650 ms sweep time) and the results were averaged. 


\section{MEASUREMENT ANALYSIS}

The main objective of these measurements is to detemine the radio coverage, related to the power - distance relationshjp in the area.

\section{III.1. Global analysis}

For each frequency $f_{j}(1 \leq j \leq m)$ chosen in considered frequency band and for each position of the $R x$ antenna, placed at a distance di $(1 \leq \mathrm{i} \leq \mathrm{n})$ from the Tx anienna, a value pij for the power loss was obtained. For each distance di, the $m$ power loss values can be averaged. As usual [1], [2], [4], assuming that, for a given distance d, the average power loss can be expressed as:

$$
\overline{\mathrm{P}}(d)=A \mathrm{~d}^{\alpha}
$$

when the logarithm of (1) is taken, the following linear relationship accrues:

$$
\overline{\mathrm{P}}(\mathrm{dB})=\mathrm{A}(\mathrm{dB})+\alpha[10 \log 10(\mathrm{~d})
$$

Using a linear regression analysis [5] between the average power loss and the distance, the minimum mean square error (MMSE) line is computed. All the results are given in Table 1.

Table 1. The results of the global analysis

\begin{tabular}{|c|c|c|c|c|c|c|}
\hline Environtunent & $h[\mathrm{~m}]$ & $a$ & $A[\mathrm{~dB}]$ & $\begin{array}{c}\text { etror } \\
{[\mathrm{dB}]}\end{array}$ & conclation & $n$ \\
\hline \multirow{2}{*}{ INSA-LOS } & 1.7 & 1.539 & 36.30 & 2.79 & 0.912 & 40 \\
\cline { 2 - 7 } & 12 & 1.164 & 36.77 & 3.98 & 0.755 & 40 \\
\hline \multirow{2}{*}{ R.ST.LOS } & 1.7 & 1.885 & 32.15 & 3.96 & 0.919 & 36 \\
\cline { 2 - 7 } & 1.2 & 1.168 & 37.90 & 4.89 & 0.742 & 36 \\
\hline \multirow{2}{*}{ R.ST.-OLOS } & 1.7 & 2.048 & 36.54 & 3.46 & 0.731 & 57 \\
\cline { 2 - 7 } & 1.2 & 1.844 & 41.06 & 421 & 0.620 & 57 \\
\hline
\end{tabular}

We can see that $\alpha<2$ for LOS environments. This indicates a wave guiding effect [6]. The corridor placed at the railway station (R.ST.-LOS) is larger than the other one (INSA-LOS); the top of the corridor presents an open zone and the ceiling is higher. For this environment, the propagation conditions resemble those associated with fre-space. Thus, $\alpha$ is closer to 2 . However, it can be observed that $\alpha<2$ indicates a weak guiding effect. For the OLOS environment (R.ST.-OLOS), for $h=1.7 \mathrm{~m}_{4}$ the measurements indicate $\alpha>2$. Thus, the propagation conditions are more difficult for the OLOS environments.

As a general remark, $\alpha$ is greater for $h=1.7 \mathrm{~m}$. For $\mathrm{h}=1.2 \mathrm{~m}$, the results obtained for LOS environments are almost the same. This indicates that for smaller values of $h_{r}$ the difference between the two environments is not very important.

\section{ItI.2. Analysis for each Prequency}

The results given in Table 1 represent global values, useful to characterize in a general manner the wave propagation in the considered frequency band. However, it is possible to repeal this analysis for each frequency value. Thus, for each frequency $f j$, the regression analysis between $p i j$ and di gives the values $\alpha_{j}$ and $A_{j}$. Fig. 1. shows a plot of $\alpha$ and $A$ versus frequency. 


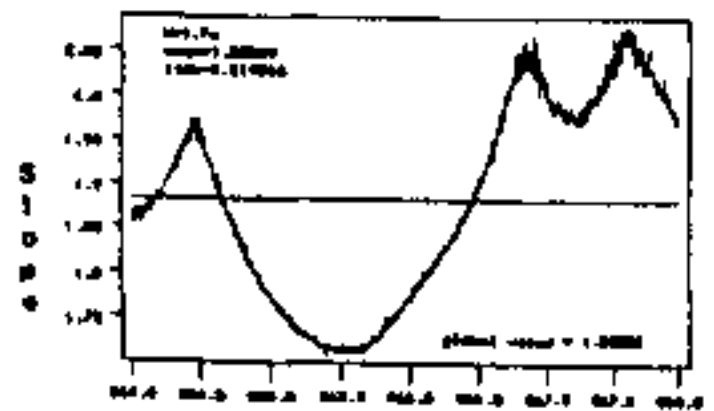

Dlohel vatte -..

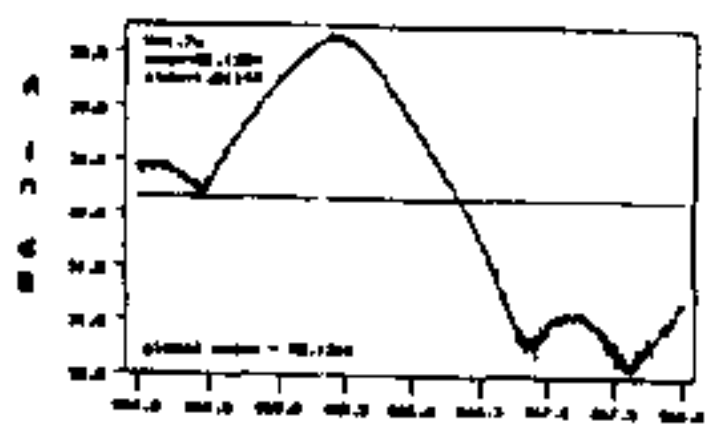

Tional value -

Fig.1. a) A plot of the slope versus frequency $(R, S T . L O S)$

b) A plot of A parameter versus frequency (R.ST.LOS)

For each parameter, the global value oblained with the first analysis is also indieated. As in [4], some important conclusions can be pointed out:

1) the indoor radio channel presents a frequency seleccivity; therefore, this analysis is useful for a better understanding of this transmission channel;

2) the averages of the $80 t$ samples for $\alpha_{j}$ and $A_{j}$ respectively are equal to the global values $\alpha$ and $A$ obtained above. This is a general result that can be mathematically proved. The global values computed at the section III. 1. can be deduced from the section III. 2 . by simple averaging over the frequency band.

\section{I,3. Analysis for ench channel}

The "Pointel" system has 40 channels and every channel has $100 \mathrm{KHz}$ bandwidth. Therefore, it is usefut to analyse the relabonship belween power loss and distance for each channel of this system. It is possible to repeat the global analysis for each $100 \mathrm{KHz}$ frequency band. However, there is an easier way to obtain the same tesults: it is sufficient to compute the average value of $\alpha$ or $\mathrm{A}$ for

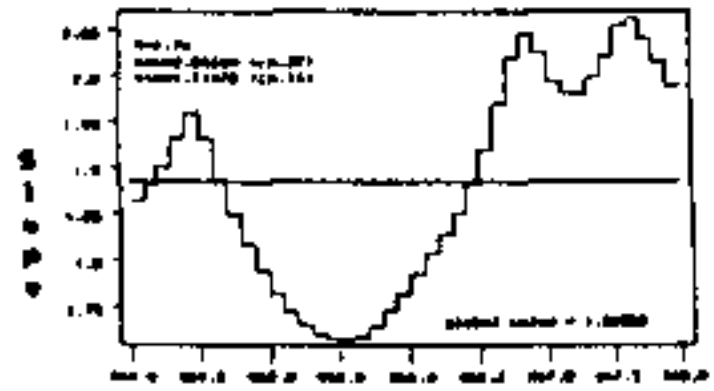

O1tared volue -

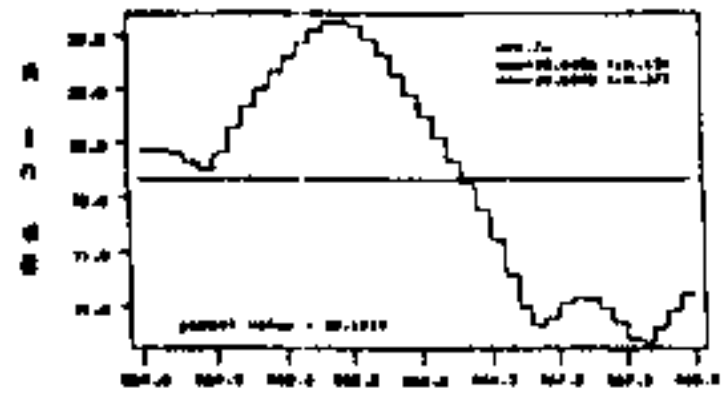

olocel wats -

Fig.2. a) A plon of the slope a for each channel b) $A$ nlor if the A narameres for ench phinntel 
cach channe]. In our case, for each channel there are 21 equidistanl frequency values, so there are 21 values for $\alpha$ and $A$. The results are presented in fig. 2. We can note the likeness with tig. J. These results can be used 10 compute the maximum distance between antennas for a given power loss value. The distances given in Table 2 were computed for $82 \mathrm{~dB}$ power loss. In each case, the analysis for each channel gives a smaller distance than the global analysis. These values assure the normal working for all the chantuets of the "Pointel" systern.

Table 2 The maximum distances between antennas

\begin{tabular}{|c|c|c|c|}
\hline Environment & $h[\mathbf{m}]$ & $\underset{\text { (global value) }}{d_{\max }}$ & $\min \left\{d_{\text {max }}\right.$ \\
\hline \multirow{2}{*}{ NSA-LOS } & 1.7 & $928 \mathrm{~m}$ & $807 \mathrm{~m}$ \\
\hline & 1.2 & $5.15 \mathrm{Km}$ & $3.7 \mathrm{Km}$ \\
\hline \multirow{2}{*}{ RST,-LOS } & 1.7 & $440 \mathrm{~m}$ & $309.5 \mathrm{~m}$ \\
\hline & 1.2 & $5.95 \mathrm{Km}$ & $918 \mathrm{~m}$ \\
\hline \multirow{2}{*}{ R.ST.-OLOS } & 1.7 & $165.6 \mathrm{~m}$ & $127.4 \mathrm{ml}$ \\
\hline & 1.2 & $165.6 \mathrm{~m}$ & $118.5 \mathrm{~m}$ \\
\hline
\end{tabular}

\section{CONCLUSIONS}

Power loss measurements of the indoor radio channels have been performed in the 864 - $868 \mathrm{MHz}$ band. Three environments were chosen and each time, two values for the height of the receiving antenna were considered. Three post processing methods were described. The obtained results were used to evaluare the radio coverage.

The distances oblained with the results of the aralysis for each channel are more reliable and accurate than those obtained with the global analysis.

The analysis described in this paper can be used for other wireless systems with several adjacent channels.

\section{ACKNOWLEDGMENTS}

This work was supported by SAT-Paris. The authors ase greatful to G.Grunfelder for his assistance in conducting the measurements.

\section{REFERENCES}

[1] Howard, S.J. and Pahlavan, K.: "Measurement and analysis of the indoor radio channel in the frequency domain", IEEE Trans., IM-39, 1990 , pp.751-755

[2] Smulders, P.F.M.,Wagemans, A.G.: "Wideband indoor radio propagation measurements at $58 \mathrm{GHz}$, Electon.Lett. Vol.28, No.13, 1992. pp. $1270-1272$

[3] Zaharia, G., El Zein, G. and Citeme, J.: "Time delay measurements in the frequency domain for indoor propagation", IEEE AP-S Dig-. 1992, pp.13881391

[4] Zaharia, G., El Zein, G. and Citeme, J.: "Wideband measuretrents and analysis of propagation losses within a building", IEEE AP-S Dig., 1992, pp. 1380-1384

[5] Urkowitz, H.: "Signal theory and random processes", Artech House lnc., Washington, 1983, Ch.7

[6] Iafortune, J.F. and Lecours, M.: "Measurement and modeling of propagation losses in a buildiag at 900 MHz", IEEE Trans., VT-39. 1990. pp. 101-108 